\title{
ANALISIS KESULITAN BELAJAR SISWA DALAM MENYELESAIKAN SOAL JURNAL PENYESUAIAN PADA MATA PELAJARAN EKONOMI
}

\author{
Oleh: Septiani Panca Putri \\ (SMA TRI DHARMA PALEMBANG)
}

\begin{abstract}
Abstrak-Tujuan penelitian ini adalah untuk mengetahui kesulitan belajar siswa dalam menyelesaikan soal jurnal penyesuaian pada mata pelajaran Ekonomi di SMA Bina Cipta Palembang. Metode penelitian yang digunakan dalam penelitian ini adalah deskriptif kualitatif dengan teknik pengumpulan data pada dokumentasi, tes, dan angket. Hasil penelitian kesalahan siswa dalam mengerjakan soal jurnal penyesuaian disebabkan oleh kesalahan dalam mencatat transaksi jurnal penyesuaian dan kesalahan dalam menganalisis transaksi jurnal penyesuaian. Kategori kesulitan belajar yang sulit yaitu beban dibayar dimuka dengan persentase kesalahan 52\%, kategori kesulitan belajar yang sedang yaitu beban yang masih harus dibayar dengan persentase kesalahan 39\% dan kategori kesulitan belajar yang mudah yaitu akun perlengkapan dengan persentase kesalahan $8 \%$. Hasil angket faktor yang menyebabkan kesulitan belajar siswa adalah kurangnya pengetahuan dan keterampilan dasar atas bahan yang dipelajari.
\end{abstract}

Kata Kunci : Kesulitan Belajar Siswa, Jurnal Penyesuaian

\begin{abstract}
The purpose of the study was to find out the learning difficulties of students in solving questions about adjusting journals on Economics subjects at Bina Cipta Palembang High School. The research method used in this study is descriptive qualitative with data collection techniques in documentation, tests, and questionnaires. The results of research on students' mistakes in working on adjusting journal problems are caused by errors in recording adjusting journal transactions and errors in analyzing adjusting journal transactions. Categories of learning difficulties are difficult, namely prepaid expenses with a percentage of errors of 52\%, moderate learning difficulties category that is accrued expenses with a percentage of errors of $39 \%$ and easy learning difficulties categories, namely equipment accounts with a percentage of errors of $8 \%$. The results of the questionnaire factors that cause student learning difficulties are the lack of basic knowledge and skills for the material being studied in the form of understanding and skills in analyzing.
\end{abstract}

Keywords: Student learning difficulties, Adjustment Journal 


\section{PENDAHULUAN}

Belajar adalah proses perkembangan diri individu yang bertujuan mengadakan suatu bentuk perubahan perilaku, sikap, ilmu pengetahuan dan keterampilan. Dalam proses pembelajaran di sekolah hasil belajar siswa diukur melalui prestasi akademik siswa yang dinilai dari tiga ranah kemampuan yaitu kognitif, afektif dan psikomotorik. Kognitif yaitu kemampuan siswa mengenai pengetahuan, pemahaman, penalaran, analisis, dan evaluasi dalam menerima informasi yang diberikan oleh guru dalam proses pembelajaran. Afektif yaitu kemampuan yang berhubungan dengan kemampuan siswa dalam mengelola emosi yang terdiri atas penilaian sikap terhadap guru dan sesama siswa. Psikomotorik yaitu kemampuan siswa dalam keterampilan jasmani. Dengan mengukur ketiga ranah kemampuan ini seseorang dapat mengamati perubahan perilaku, sikap, dan pengetahuan setelah siswa belajar dan membandingkannya. Pembelajaran adalah suatu proses pendidikan secara keseluruhan dengan pendidik sebagai pembimbing dalam memberikan pembelajaran dan motivasi kepada siswa. Dalam proses pembelajaran siswa sering kali mengalami hambatan dalam mencapai tujuan belajar. Hambatan ini dalam ilmu pendidikan disebut sebagai kesulitan belajar. Kesulitan belajar adalah permasalahan yang menghambat dalam proses belajar mengajar sehingga tidak tercapainya keberhasilan pembelajaran.

Menurut Djamarah (2011, hal.235) "Kesulitan belajar adalah suatu kondisi dimana anak didik tidak dapat belajar secara wajar, disebabkan adanya ancaman, hambatan ataupun gangguan dalam belajar. Dapat dijelaskan bahwa kesulitan belajar merupakan suatu kondisi dimana siswa mengalalami hambatan dalam proses pembelajaran sehingga menyebabkan kegagalan dalam mencapai prestasi belajar.

Kesulitan belajar sering kali dikaitkan dengan kegagalan pencapaian prestasi belajar siswa. Menurut Abdurrahman prestasi belajar dipengaruhi oleh dua faktor, yaitu faktor internal dan faktor eksternal (Djamarah, 2011; 235),

1) Penyebab utama kesulitan belajar (learning disabilities) adalah faktor internal, yaitu kemungkinan adanya disfungsi neurologis. Disfungsi neurologis adalah gangguan dalam sistem saraf otak yang disebabkan oleh berbagai faktor, antara lain faktor keturunan, kerusakan pada fungsi otak, gizi yang tidak memadai, dan pengaruh-pengaruh psikologis dan sosial lainnya.

2) Faktor eksternal, yaitu berasal dari luar diri siswa berupa strategi pembelajaran yang keliru, pengelolaan kegiatan 
pembelajaran yang tidak membangkitkan motivasi dan pemberian ulangan penguatan yang tidak tepat.

Kegagalan siswa untuk mencapai hasil belajar yang maksimal diduga karena beberapa faktor. Faktor yang pertama adalah faktor yang berasal dari dalam diri siswa, persepsi siswa materi jurnal penyesuaian terlalu sulit untuk dipahami, sehingga minat belajar siswa menjadi rendah. Faktor kedua yaitu faktor yang berasal dari luar diri siswa, metode pembelajaran ceramah dan resitasi yang digunakan selama ini di SMA Bina Cipta Palembang pada mata pelajaran ekonomi dinilai sudah cukup baik tetapi belum optimal hal ini dilihat dari masih banyaknya siswa yang mengalami kesulitan belajar pada materi jurnal penyesuaian.

Jurnal penyesuaian merupakan proses pengikhtisaran yang mencerminkan kondisi akun dan jumlah nominal sebenarnya. Sebagai proses pengikhtisaran jurnal penyesuaian berhubungan dengan tahapan pada siklus akuntansi lainnya, sehingga pada proses ini siswa memerlukan ketelitian dan kemampuan analisis dalam penyelesaiannya. Oleh sebab itu, jurnal penyesuaian dianggap siswa sebagai bagian tersulit dalam pembelajaran akuntansi. Berdasarkan informasi awal yang diperoleh peneliti dari guru yang mengajar terdapat kesulitan belajar akuntansi pada materi jurnal penyesuaian di kelas XII IPS SMA Bina Cipta Palembang. Kesulitan belajar itu dilihat dari kurangnya keaktifan siswa selama proses pembelajaran berlangsung, dimana siswa cenderung pasif saat guru bertanya dan saat diberikan tugas hanya sebagian siswa yang mengerjakan tugas sedangkan sebagian lagi menyalin tugas yang dikerjakan temannya. Hal ini mengakibatkan siswa yang mengalami kesulitan belajar dalam menyelesaikan soalsoal akuntansi khususnya jurna penyesuaian banyak yang tidak bisa menyelesaikan soal jurnal penyesuaian yang diberikan.

Permasalahan berdampak pada hasil belajar siswa yang terlihat dari nilai rata-rata ulangan harian siswa yang belum mencapai KKM, yaitu 75. Hal ini dapat dilihat dari ketuntasan siswa 40\%, sedangkan $60 \%$ dibawah KKM. Hal ini tentu saja tidak sesuai dengan hasil belajar yang diharapkan oleh guru.Untuk itu peneliti berkeinginan meneliti tentang kesulitan belajar siswa dalam menyelesaikan soal jurnal penyesuaian dengan harapan hasil belajar siswa akan lebih baik dan meningkat setelah diketahui faktorfaktor yang menyebabkan siswa mengalami kesulitan belajar dan alternatif cara mengatasi kesulitan belajar siswa. Berdasarkan permasalahan yang dialami siswa seperti yang diuraikan di atas maka peneliti berkeinginan untuk 
mengadakan penelitian dengan judul "Analisis Kesulitan Belajar Siswa dalam Menyelesaikan Soal Jurnal Penyesuaian Pada Mata Pelajaran Ekonomi di SMA Bina Cipta Palembang Tahun Pelajaran 2018/2019"

\section{METODE PENELITIAN}

Menurut Sugiyono (2010: 43) "Metode penelitian adalah cara ilmiah untuk mendapatkan data yang valid dengan tujuan dapat ditemukan, dikembangkan, dan dibuktikan". Kesulitan belajar sebagai salah satu gejala sosial yang sulit diukur karena kemampuan belajar siswa yang berbeda-beda, maka dalam mencapai tujuan dalam penelitian ini digunakan metode deskriptif dengan pendekatan kualitatif.

Menurut Nazir (2014) "Metode deskriptif adalah suatu metode dalam meneliti status kelompok manusia, suatu objek, suatu set kondisi, suatu sistem pemikiran, ataupun suatu kelas peristiwa pada masa sekarang". Sedangkan metode kualitatif sering disebut metode penelitian naturalistic karena penelitiannya dilakukan pada kondisi yang alamiah (natural setting) disebut kualitatif karena data yang terkumpul dan analisisnya lebih bersifat kualitatif.

Metode penelitian deskriptif dengan pendekatan kualitatif dalam penelitian ini bertujuan untuk mengetahui penyebab kesulitan belajar siswa kelas XII dalam menyelesaikan jurnal penyesuaian pada mata pelajaran Ekonomi di SMA Bina Cipta Palembang tahun pelajaran 2018/2019.

\section{Teknik Analisis Data}

Menurut Arikunto "Teknik analisis data merupakan cara yang digunakan untuk mengelola data yang terkumpul dan diklasifikasikan sesuai dengan tujuan penelitian". Analisis data yang digunakan dalam penelitian ini adalah analisis data secara deskriptif.

\section{Teknik Analisis Data Tes}

Dalam menganalisa data tersebut peneliti menempuh langkahlangkah sebagai berikut:

1. Menilai hasil tes yang diperoleh oleh siswa dengan mengubah skor mentah hasil tes menjadi nilai standar: $S=\frac{\text { jumlah jawaban yang benar }}{\text { jumlah soal }} \times 100$ (Arifin, 2016: 229).

2. Melakukan analisis persentase distribusi nilai siswa pada setiap kriteria penilaian dengan rumus: $p=\frac{f}{n} \times 100 \%$

(Sudijono, 2010: 43).

Keterangan:

F : Frekuensi persentase siswa pada tiap kriteria

$\mathrm{N}$ : Jumlah siswa sampel

$\mathrm{P}$ : Angka persentase

3. Menginterprestasikan nilai siswa ke dalam kriteria penelitian seperti tabel berikut: 
Tabel 1. Kriteria Penilaian

\begin{tabular}{|c|c|c|c|}
\hline Interval Nilai & Bobot Nilai & Nilai Huruf & Kategori Hasil \\
\hline $86-100$ & 4 & A & Baik Sekali \\
\hline $71-85$ & 3 & B & Baik \\
\hline $56-70$ & 2 & C & Cukup \\
\hline $41-55$ & 1 & D & Kurang \\
\hline$<40$ & 0 & E & Sangat Kurang \\
\hline
\end{tabular}

(Sumber : Depdiknas, 2007:32)

Dari tabel diatas bahwa siswa yang memperoleh nilai dibawah Kriteria Ketuntasan Minimum (KKM) yaitu 75 dikategorikan sebagai berkesulitan belajar.

\section{Teknik Analisis Data Angket}

Dalam menganalisa data tersebut peneliti menempuh langkahlangkah sebagai berikut:

1) Menyebarkan angket kepada siswa

2) Melakukan perhitungan dengan menggunakan rumus :

$p=\frac{f}{n} \times 100 \%$

(Sudijono, 2010: 43)

\section{Keterangan:}

F : Frekuensi persentase siswa pada tiap kriteria

$\mathrm{N}$ : Jumlah siswa sampel

$\mathrm{P}$ : Angka persentase

\section{HASIL PENELITIAN}

Penelitian dilakukan di SMA Bina Cipta bertempat di Jalan Bina Cipta No.18, Bukit Sangkal, Kalidoni, Kota Palembang, Provinsi Sumatera Selatan, dengan jumlah siswa yang menjadi sampel sebanyak 32 siswa kelas XII IPS 2.untuk mengetahui kesulitan siswa dalam menyelesaikan soal jurnal penyesuaian di SMA Bina Cipta Palembang melalui pemberian tes. Berdasarkan nilai hasil tes siswa materi jurnal penyesuaian diketahui bahwa, siswa yang mencapai nilai (86-100) sebanyak 4 orang siswa dengan kategori "Baik Sekali" dan pada barang dagang sebesar $50 \%$ dan rata-rata keseluruhan kesalahan siswa dalam menganalisis transaksi jurnal penyesuaian sebesar $40 \%$ dengan persentase kesalahan tertinggi pada materi beban dibayar dimuka sebesar $52 \%$.

Berdasarkan hasil angket faktor intern dan faktor ekstern pada tabel di atas diketahui keseluruhan rata-rata faktor intern kesulitan belajar siswa dalam menyelesaikan soal jurnal penyesuaian sebesar 52, 05\% yang meliputi aspek kognitif, afektif dan psikomor sedangkan rata-rata keseluruhan faktor ekstern kesulitan belajar siswa sebesar 50, 28\% yang meliputi lingkungan keluarga dan lingkungan sekolah. Berdasarkan hasil penelitian soal tes kesulitan belajar siswa dalam menyelesaikan soal jurnal penyesuaian. Kesulitan 
siswa dalam menyelesaikan soal jurnal penyesuaian disebabkan oleh kesalahan mencatat transaksi jurnal penyesuaian dan menganalisis transaksi jurnal penyesuaian. Ratarata keseluruhan kesalahan siswa dalam mencatat transaksi jurnal penyesuaian sebesar $60 \%$ dan ratarata keseluruhan kesalahan siswa dalam menganalisis transaksi jurnal penyesuaian sebesar $40 \%$. Kemudian kesulitan belajar siswa yang heterogen ini dikelompokan menjadi 3 kategori untuk mengetahui pada materi jurnal penyesuaian manakah yang menjadi kesulitan belajar siswa.

Ada 3 kategori kesulitan belajar siswa, yaitu Sulit, Sedang dan Mudah. Berikut ini deskripsi kesulitan belajar siswa dari ketiga kategori kesulitan belajar siswa dalam menyelesaikan soal jurnal penyesuaian adalah sebagai berikut:

1. Pada kategori ini ada 2 materi jurnal penyesuaian yang sering menyebabkan kesulitan belajar siswa dalam menyelesaikan soal jurnal penyesuaian yaitu materi beban dibayar dimuka dengan persentase kesalahan $52 \%$ dan persediaan barang dagang dengan persentase kesalahan $50 \%$.

2. Pada kategori sedang ada 4 materi jurnal penyesuaian yang menyebabkan kesulitan belajar siswa dalam menyelesaikan soal jurnal penyesuaian yaitu materi beban yang masih harus dibayar sebesar 39\%, pendapatan yang masih harus diterima sebesar
$37 \%$, pendapatan diterima dimuka sebesar 32\%, dan penyusutan aktiva tetap sebesar $20 \%$.

3. Pada kategori mudah materi jurnal penyesuaian yang menyebabkan kesulitan belajar siswa dalam menyelesaikan soal jurnal penyesuaian yaitu materi akun peralatan sebesar $8 \%$. Kesulitan belajar biasanya tampak jelas dari menurunnya kinerja akademik atau prestasi belajar yang dicapai siswa. Rendahnya kinerja akademik siswa dalam menyelesaikan soal jurnal penyesuaian dilihat dari hasil tes siswa dibawah KKM sebesar $68,7 \%$.

Hasil tes siswa yang rendah menunjukan adanya kesulitan belajar siswa dalam menyelesaikan soal jurnal penyesuaian. Berdasarkan hasil tes siswa kategori kesulitan belajar yang sulit yaitu beban dibayar dimuka dengan persentase kesalahan $52 \%$, kategori kesulitan belajar yang sedang yaitu beban yang masih harus dibayar dengan persentase kesalahan 39\% dan kategori kesulitan belajar yang mudah yaitu akun perlengkapan dengan persentase kesalahan 8\%. Penyebab kesulitan belajar siswa hasil dalam menyelesaikan soal jurnal penyesuaian berdasarkan hasil angket siswa diketahui bahwa kesulitan belajar siswa dalam jurnal penyesuaian disebabkan oleh kurangnya pengetahuan dan keterampilan dasar atas bahan yang dipelajari berupa pemahaman dan 
keterampilan dalam menganalisis dan mencatat data transaksi; kurangnya minat belajar siswa terhadap materi jurnal penyesuaian; metode mengajar guru yang kurang menarik saat pelajaran akuntansi serta kurang lengkapnya prasarana pembelajaran seperti persediaan buku pelajaran akuntansi yang kurang memadai.

\section{PEMBAHASAN}

Penelitian dilakukan di SMA Bina Ciptabertempat di Jalan Bina Cipta No.18, Bukit Sangkal, Kalidoni, Kota Palembang, Provinsi Sumatera Selatan Berdasarkan data yang diperoleh peneliti ke sekolah populasi dalam penelitian ini adalah sebanyak 64 siswa kelas XII IPS tahun pelajaran 2018/2019. Penelitian ini dilaksanakan mulai tanggal 18 Juli 2018 sampai dengan 30 Agustus 2018 yang bertujuan untuk mengetahui kesulitan belajar siswa dalam menyelesaikan soal jurnal penyesuaian pada mata pelajaran akuntansi.

Tahapan menganalisis transaksi merupakan salah satu tahap yang sangat penting dalam akuntansi akan tetapi pada tahap menganalisis siswa merasa kesulitan dalam mamahaminya sehingga berdampak pada pencapaian hasil belajar yang tidak maksimal. Dan dari hasil tes siswa keseluruhan diperoleh siswa sebanyak 22 siswa dengan presentase sebesar 68,7\% mengalami kesulitan belajar. Sedangkan hanya 31,3\% sebanyak 10 siswa yang tidak mengalami kesulitan belajar dalam materi jurnal penyesuaian.

Berdasarkan hasil penelitian soal tes kesulitan belajar siswa dalam menyelesaikan soal jurnal penyesuaian yang dapat dilihat pada diagram 4.8. Kesulitan siswa dalam menyelesaikan soal jurnal penyesuaian disebabkan oleh kesalahan mencatat transaksi jurnal penyesuaian dan menganalisis transaksi jurnal penyesuaian. Ratarata keseluruhan kesalahan siswa dalam mencatat transaksi jurnal penyesuaian sebesar 60\%dan ratarata keseluruhan kesalahan siswa dalam menganalisis transaksi jurnal penyesuaian sebesar $40 \%$. Kemudian kesulitan belajar siswa yang heterogen ini dikelompokan menjadi 3 kategori untuk mengetahui pada materi jurnal penyesuaian manakah yang menjadi kesulitan belajar siswa yang disajikan dalam tabel 4.5 dibawah ini. 
Tabel 2. Kategori Kesulitan Belajar Siswa Menyelesaikan Soal Jurnal

Penyesuaian

\begin{tabular}{|c|l|l|l|c|}
\hline No & \multicolumn{1}{|c|}{$\begin{array}{c}\text { Kategori } \\
\text { Kesulitan Belajar }\end{array}$} & $\begin{array}{c}\text { Indikator Kesulitan } \\
\text { Belajar }\end{array}$ & $\begin{array}{c}\text { Deskripsi Kesulitan } \\
\text { Belajar }\end{array}$ & $\%$ \\
\hline 1 & Sulit & Beban dibayar dimuka & $\begin{array}{l}\text { Menganalisis transaksi } \\
\text { jurnal }\end{array}$ & $52 \%$ \\
\hline 2 & Sedang & $\begin{array}{l}\text { Beban yang masih } \\
\text { harus dibayar }\end{array}$ & $\begin{array}{l}\text { Mencatat transaksi } \\
\text { jurnal }\end{array}$ & $39 \%$ \\
\hline 3 & Mudah & Perlengkapan & $\begin{array}{l}\text { Menganalisis transaksi } \\
\text { jurnal }\end{array}$ & $8 \%$ \\
\hline
\end{tabular}

Sumber: Diolah Dari Hasil Penelitian

Berdasarkan tabel diatas diketahui ada 3 kategori kesulitan belajar siswa, yaitu Sulit, Sedang dan Mudah. Berikut ini deskripsi kesulitan belajar siswa dari ketiga kategori kesulitan belajar siswa dalam menyelesaikan soal jurnal penyesuaian adalah sebagai berikut:

\section{Kategori Kesulitan Belajar Siswa} Sulit

Pada kategori ini ada 2 materi jurnal penyesuaian yang sering menyebabkan kesulitan belajar siswa dalam menyelesaikan soal jurnal penyesuaian yaitu materi beban dibayar dimuka dengan persentase kesalahan $52 \%$ dan persediaan barang dagang dengan persentase kesalahan 50\%. Pada materi jurnal penyesuaian beban dibayar dimuka soal nomor 3 merupakan soal dengan persentase kesalahan tertinggi siswa, dimana pada soal ini sebanyak 17 siswa salah menganalisis transaksi jurnal dikarenakan salah menghitung bulan yang sudah menjadi beban, yang seharusnya 7 bulan menjadi 6 bulan.
Persediaan barang dagang mempunyai dua pencatatan jurnal, yaitu pencatatan dengan pendekatan laba rugi dan pencatatan dengan pendekatan neraca. Soal nomor 14 dan soal nomor 18 menggunakan pendekatan laba rugi, rata-rata kesalahan siswa disebabkan kekeliruan dalam mencatat jurnal dimana pada soal nomor 14 sebanyak 16 siswa salah menjurnal, yaitu mendebit persediaan barang dagang awal dan mengkredit persediaan barang dagang akhir.

Kesalahan pencatatan ini terjadi diakibatkan kurangnya pemahaman siswa terhadap materi jurnal persediaan barang dagang dimana materi ini baru dipelajari siswa pada semester ganjil kelas XII. Berbeda dengan enam materi jurnal penyesuaian lain yang telah dipelajari pada semester genap kelas XI. 


\section{Kategori Kesulitan Belajar Siswa Sedang}

Pada kategori sedang ada 4 materi jurnal penyesuaian yang menyebabkan kesulitan belajar siswa dalam menyelesaikan soal jurnal penyesuaian yaitu materi beban yang masih harus dibayar sebesar 39\%, pendapatan yang masih harus diterima sebesar $37 \%$, pendapatan diterima dimuka sebesar $32 \%$, dan penyusutan aktiva tetap sebesar $20 \%$.

Pada materi jurnal penyesuaian beban yang masih harus dibayar soal nomor 13 menunjukan sebanyak 18 siswa menjawab soal dengan benar dan 14 siswa salah mencatat transaksi jurnal. Kesalahan pencatatan yang dilakukan oleh siswa adalah dengan mencatat akun hutang gaji disebelah debit dan akun beban gaji disebelah kredit, yang seharusnya akun beban gaji disebelah debit dan akun hutang gaji disebelah kredit. Pada materi jurnal penyesuaian pendapatanyang masih harus diterima rata-rata kesalahan tertinggi siswa ada pada soal nomor 10 sebanyak 22 siswa menjawab soal dengan benar dan sebanyak 11 siswa salah mencatat transaksi jurnal. Kurangnya pemahaman dasar siswa terhadap akun, menyebabkan siswa salah menjurnal yaitu mendebit akun penjualan dan menkredit akun piutang usaha.

Pada materi jurnal penyesuaian pendapatan diterima dimuka rata-rata kesalahan tertinggi siswa ada pada butir soal nomor 7 sebanyak 14 siswa salah dalam menganalisis transaksi jurnal. Kesalahan yang dilakukan oleh siswa yaitu menghitung saldo peralatan toko dikurang penyusutan setiap tahun menjadi Rp.400.000 yang seharusnya hanya mencatat nominal penyusutan setiap tahun Rp.100.000.

\section{Kategori Kesulitan Belajar Siswa Mudah}

$\begin{array}{llr}\text { Pada } & \text { kategori mudah materi } \\ \text { jurnal } & \text { penyesuaian yang }\end{array}$ menyebabkan kesulitan belajar siswa dalam menyelesaikan soal jurnal penyesuaian yaitu materi akun peralatan sebesar8\%. Pada materi akun perlengkapan rata-rata kesalahan siswa ada pada soal nomor 2 sebanyak 10 siswa yang menjawab soal salah dikarenakan salah menganalisis transaksi jurnal. Pemahaman dasar terhadap materi jurnal penyesuaian yang kurang menyebabkan siswa salah mencatat perlengkapan terpakai menjadi perlengkapan yang tersisa. Pada soal nomor 2 rata-rata kesalahan siswa adalah mencatat beban perlengkapan Rp.200.000 yang seharusnya Rp. 400.000.

Siswa yang mengalami kesulitan belajar kemudian dibagikan angket untuk melihat faktor penyebab kesulitan belajar siswa. Hasil angket faktor intern dan faktor ekstern diketahui keseluruhan ratarata faktor intern kesulitan belajar siswa dalam menyelesaikan soal jurnal penyesuaian sebesar 52, 05\% 
sedangkan rata-rata keseluruhan faktor ekstern kesulitan belajar siswa sebesar 50, 28\%. Berdasarkan angket faktor intern kesulitan belajar siswa diketahui Kesulitan belajar ini disebabkan oleh kurangnya pengetahuan dan keterampilan dasar atas bahan yang dipelajari berupa pemahaman dan keterampilan dalam menganalisis dan mencatat data transaksi; kurangnya minat belajar siswa terhadap materi jurnal penyesuaian; metode mengajar guru yang kurang menarik saat pelajaran akuntansi serta kurang lengkapnya prasarana pembelajaran seperti persediaan buku pelajaran akuntansi yang kurang memadai.

Kesulitan belajar biasanya tampak jelas dari menurunnya kinerja akademik atau prestasi belajar yang dicapai siswa. Rendahnya kinerja akademik siswa dalam menyelesaikan soal jurnal penyesuaian dilihat dari hasil tes siswa keseluruhan diperoleh dari 32 siswa sebanyak 22 siswa nilainya dibawah KKM dengan presentase sebesar $68,7 \%$.

Hasil tes siswa yang rendah menunjukan adanya kesulitan belajar siswa dalam menyelesaikan soal jurnal penyesuaian. Berdasarkan hasil tes siswa kategori kesulitan belajar yang sulit yaitu beban dibayar dimuka dengan persentase kesalahan $52 \%$, kategori kesulitan belajar yang sedang yaitu beban yang masih harus dibayar dengan persentase kesalahan $39 \%$ dan kategori kesulitan belajar yang mudah yaitu akun perlengkapan dengan persentase kesalahan $8 \%$. Penyebab kesulitan belajar siswa hasil dalam menyelesaikan soal jurnal penyesuaian berdasarkan hasil angket siswa diketahui bahwa kesulitan belajar siswa dalam jurnal penyesuaian disebabkan oleh kurangnya pengetahuan dan keterampilan dasar atas bahan yang dipelajari berupa pemahaman dan keterampilan dalam menganalisis dan mencatat data transaksi; kurangnya minat belajar siswa terhadap materi jurnal penyesuaian; metode mengajar guru yang kurang menarik saat pelajaran akuntansi serta kurang lengkapnya prasarana pembelajaran seperti persediaan buku pelajaran akuntansi yang kurangmemadai.

\section{KESIMPULAN}

Berdasarkan hasil penelitian mengenai kesulitan belajar siswa dalam menyelesaikan soal jurnal penyesuaian perusahaan dagang pada mata pelajaran Ekonomi kelas XII IPS di SMA Bina Cipta Palembang tahun pelajaran 2018/2019, dapat disimpulkan bahwa Hasil tes siswa dalam menyelesaikan soal jurnal penyesuaian perusahaan dagang di SMA Bina Cipta Palembang, yaitu kesalahan siswa dalam mengerjakan soal jurnal penyesuaian disebabkan oleh kesalahan dalam mencatat transaksi jurnal penyesuaian dan kesalahan dalam menganalisis transaksi jurnal penyesuaian. 
Kategori kesulitan belajar yang sulit yaitu beban dibayar dimuka dengan persentase kesalahan 52\%, kategori kesulitan belajar yang sedang yaitu beban yang masih harus dibayar dengan persentase kesalahan 39\% dan kategori kesulitan belajar yang mudah yaitu akun perlengkapan dengan persentase kesalahan $8 \%$.

Hasil analisis angket faktor yang menyebabkan kesulitan belajar siswa dalam menyelesaikan soal jurnal penyesuaian di SMA Bina Cipta Palembang. Diketahui keseluruhan rata-rata faktor intern kesulitan belajar siswa dalam menyelesaikan soal jurnal penyesuaian sebesar 52, $05 \%$ sedangkan rata-rata keseluruhan faktor ekstern kesulitan belajar siswa sebesar 50, 28\%. Berdasarkan angket faktor intern kesulitan belajar siswa diketahui kesulitan belajar ini disebabkan oleh kurangnya pengetahuan dan keterampilan dasar atas bahan yang dipelajari berupa pemahaman dan keterampilan dalam menganalisis dan mencatat data transaksi; kurangnya minat belajar siswa terhadap materi jurnal penyesuaian; metode mengajar guru yang kurang menarik saat pelajaran akuntansi serta kurang lengkapnya prasarana pembelajaran seperti persediaan buku pelajaran akuntansi yang kurang memadai.

\section{DAFTAR PUSTAKA}

Arifin, Zainal. (2016). Evaluasi

Pembelajaran Prinsip, Teknik, dan Prosedur, Bandung: PT. Remaja Rosdakarya.

Arikunto. (2013). Prosedur Penelitian Suatu Pendekatan Praktik. Jakarta: Rineka Cipta

Djamarah, Syaiful Bahri. (2011). Psikologi Belajar. Jakarta: Rineka Cipta.

Nazir, Moh. (2014). Metode Penelitian. Bogor: Ghalia Indonesia

Sudijono, Anas. (2010). Pengantar Statistik Pendidikan. Jakarta: PT. Rajafindo Persada 